\title{
PEDAGÓgUSOK INTERPERSZONÁLIS KOMMUNIKÁCIÓJA
}

\section{BARACSI ÁGNeS}

\author{
a Nyíregyházi Főiskola Pedagógusképző Karának \\ föiskolai docense \\ baracsia@nyf.hu
}

\begin{abstract}
Kutatásunk a pedagógusok kompetenciáinak egy kevésbé feltárt területét, a személyes és társas kompetenciákat vizsgálta. A kutatás legföbb kérdése az volt, rendelkeznek-e a pedagógusok azokkal a személyes és társas kompetenciákkal, melyek kialakitását, fejlesztését, közvetitését tölük várják. Az eredmények arra utalnak, hogy a vizsgált tanárok személyes és társas kompetenciáik bizonyos területein lemaradást mutatnak. Legjellemzöbb e téren a kommunikációs és érzelmi képességeik (érzelmi intelligenciájuk) alacsonyabb szintje. Tanulmányunkban a pedagógusok interperszonális kommunikációjának sajátosságait mutatjuk be.
\end{abstract}

\section{Pedagógusok körében végzett kompetenciavizsgálatok}

Számos kritika és észrevétel fogalmazódott meg már azzal kapcsolatban, hogy miközben sorra születnek a pedagógusokról, illetve a számukra kívánatosnak vélt kompetenciákról szóló elvi állásfoglalások, valójában alig van arra vonatkozó tapasztalat, most milyen kompetenciákkal rendelkeznek a pedagógusok (Sági, 2006).

A téma „újszerüsége” miatt valóban kevesebb a rendelkezésünkre álló empirikus adat, mégis van némi rálátásunk arra - bár még inkább mozaikokban -, hogyan gondolkodnak a pedagógusok a kompetenciáról, a kompetenciafejlesztésről, a szakmai kompetenciájuk különböző területeiről. A továbbiakban e kutatások eredményeiből mutatunk be néhányat.

A magyar közoktatás kilencvenes évek végi átalakításának pedagógusokra gyakorolt hatását paradox módon szimbolizáló „csak reformot ne...!” hangulat ${ }^{1}$ napjainkban kis túlzással átfordítható „,csak kompetenciát ne...!” hangulatra. Szekszárdi Júlia egy 2006-ban publikált kutatásában ${ }^{2}$ igazgatókkal rangsoroltatta milyen célok (az alkalmazkodás; a jó légkör; az eredményesség és hatékonyság; a fennmaradás és a pénz; a hátrányos helyzetüek beillesztése; a kompetenciafejlesztés és

\footnotetext{
${ }^{1}$ A szlogen Lukács Péter és Várhegyi György (1989, szerk.): Csak reformot ne..., Educatio, Budapest, könyvének címe.

${ }^{2}$ Szekszárdi Júlia (2006): Az iskolák belső világa. In: Halász Gábor és Lannert Judit (szerk.): Jelentés a magyar közoktatásról. Országos Közoktatási Intézet, Budapest. A megnevezett célokat a fejezet 6.1. táblázata tartalmazza, mely forrásként „Az iskolai eredményesség vizsgálata 2005.” címü kutatásra hivatkozik.
} 
a kultúra-, értékközvetítés) megvalósítását tartják legfontosabbnak az iskolájukban. A kutatás arra hívta fel a figyelmet, hogy a hivatalos oktatáspolitika által hangoztatott célok, mint a készségfejlesztés, az integráció vagy a kompetenciafejlesztés csak a felszínen kiemelt célok, valójában az iskola fenntartását és az eredményességet tartják fontosnak az intézményvezetők. A tanulmány szerzője megállapította, a pedagógusok valódi céljai és az oktatáspolitikai elvárások nem esnek egybe.

Egy másik kutatásban ugyanezeket a célokat rangsorolta 50 pedagógus, akik szintén nem tartották a kompetenciafejlesztést iskolájuk fontos feladatának. Mindennapi munkájukban olyan „hagyományos” pedagógiai funkciók ellátását tartották kiemelt feladatnak, mint a kultúra átadása, az intellektuális fejlesztés és ahhoz szorosan kötődő eredményesség. Mindenképpen elgondolkodtató - főleg a jövő tanáraival szembeni uniós elvárások ismeretében -, hogy a társadalmi beilleszkedés segítése és a külső igényekhez, feltételekhez való alkalmazkodás háttérbe szorul a pedagógusok rangsorában (Baracsi, 2009).

„A katedra árnyékában” (Ollé és Perjés, 2006) címü, a tanárjelöltek kulcskompetenciáinak különböző dimenzióit bemutató tanulmánykötet öt kulcskompetencia vizsgálatát tủzte ki célul: az összetettséggel való megbirkózást, a helyes megitélést, a normativitást, az együttmüködést képessé tevő és a narratív (elbeszélő) kompetenciákat. A kutatást közel 500 hallgató segítette on-line kérdőív kitöltésével, hat hazai felsőoktatási intézményböl.

A tanárjelöltek a tanulók nevelése-oktatása során leginkább a hatékony kommunikáció, a lényegkiemelés és a jó döntési képesség erősítését tartják kiemelt feladatuknak, a szabálytudathoz, az információ kezeléséhez és értelmezéséhez, valamint a kritikai gondolkodás kimunkálásához szükséges kompetenciák fejlesztését viszont háttérbe szorítják. Önjellemzésükben mind az öt kulcskompetenciához kapcsolódó tevékenységekre egyaránt alkalmasnak tartják magukat, és az alkalmasságukról alkotott képük nem differenciálódik a kulcskompetenciák mentén. Így a kutatók azt a megállapítást tették, hogy a tanárjelöltek vagy nem tudják saját alkalmasságukat differenciáltan értékelni, vagy az ténylegesen is differenciálatlan.

Témánkhoz kötődő egyik fontos megállapítás a perceptivitás és a kommunikációra való alkalmasság minősítésére vonatkozik. A tanárjelöltek legbiztosabbak abban, hogy figyelmet tudnak mutatni a tanulók felé, míg legproblémásabbnak a nonverbális jelzések szabályozását és a tanulókra vonatkozó érzelmek kifejezését találták. Ezért a fejlesztésben kiemelten fontosnak tartják a szerzők a gyakorlati képzést (mikrotanítás, külső iskolai gyakorlat), ugyanis itt van mód arra, hogy olyan visszajelzéseket kapjanak a jelöltek, melyek befolyásolják énképüket. Egy másik észrevétel az együttmüködési kompetenciájuk sajátosságaira hívja fel a figyelmet. Alkalmasabbnak vélik a hallgatók magukat a kezdeményező vagy reagáló interperszonális kapcsolatokra, ezzel szemben kevésbé kedvező az önmegítélésük a csoportos együttmüködés facilitálása szempontjából, illetve más olyan tevékeny- 
ségek során, mely tanítási gyakorlatot, módszertani tapasztalatot vagy motiváló együttmüködést igényel.

Nagy Mária (2008) egy nemzetközi projekt keretei között végzett összehasonlító vizsgálat tanári kompetenciákra vonatkozó eredményeit publikálta. A nemzetközi kutatócsoport által összeállított 39 itemes kompetencialista azt vizsgálta, hogy a szakiskolai nevelők mennyire tartják fontosnak az egyes kompetenciákat, illetve milyen mértékben rendelkeznek ezekkel a kompetenciákkal. Mindhárom ország tanárai az interperszonális és didaktikai kompetenciák meglétét tartják a legfontosabbnak, míg a szaktárgyi fejlesztés és saját szakmai fejlődésük irányítása éppúgy a lista végére került, mint a diákoknak szóló tanácsadás és diagnosztikus eljárások ismerete, vagy a szervezési feladatok.

Saját kompetensségük megítélésére alacsonyabb pontszámokat adtak a tanárok maguknak, mint amennyire fontosnak tartják azokat munkájukban. A szaktárgyi-didaktikai (szaktárgyukat uralni és megtanítani, lelkesedni saját tárgyuk és a tanulók tárgyban mutatott fejlödése iránt) és az interperszonális kompetenciákban (együttmúködés és bizalom légköre, meleg szívvel fordulni a diákokhoz) érzik erősnek magukat.

Érdekes tanulságokkal szolgál a kutatás. Az egyik tanulság, hogy a kutatásban részt vevő tanárok egy része az Equal projektben is részt vett. Kilenc olyan kompetencia volt, amelyet szignifikánsan magasabbra értékeltek a projektben résztvevők, mint társaik. Azaz a képzés szemléletváltoztatásra alkalmas, de nem jelenti automatikusan a képesség kialakulását. Vagyis a pedagógusok hiába hallottak többet a kompetenciák jelentőségéről, vagy láttak rá jól müködő tapasztalatokat, a kompetenciák kialakulása hosszabb folyamatot és gyakorlati feltételek meglétét kívánja meg. Az adott készségek fontosságának felismerése tehát csak az első lépés azok kialakításához és begyakorlásához, ehhez a szakmai kultúrát befolyásoló egyéb tényezőknek is rendelkezésre kellene állnia. Másik fontos tanulság, hogy a magyar (és az olasz) pedagógusok szakmai kultúrájához a „korlátozott tanári felfogás” (osztályteremre fókuszáló), míg a holland pedagógusokhoz a „kiterjesztett szerepfelfogás" (az iskola külső kapcsolatrendszere és feladatai iránt nyitottabb viszonyulás) áll közelebb. A harmadik észrevétel a pedagógusok saját felkészültségének deficitjéről számol be, mely alapján jól körvonalazódik, hogy a pedagógusok milyen területen várnak segítséget a képzéseken és továbbképzéseken. Ezek a területek: a tanulók motiválása, a tanulókkal való együttmüködés és kölcsönös bizalom kiépítése, a szülök világának és a tanulók kulturális hátterének megismerése (Nagy, 2008).

2008-ban 50 Szabolcs-Szatmár-Bereg megyei pedagógust kérdeztünk a személyes és társas kompetenciáik sajátosságairól, melyhez Havas Péter 15 itemből álló kompetenciarendszerét ${ }^{3}$ vettük alapul (Baracsi, 2009). Tapasztalataink a követ-

\footnotetext{
${ }^{3}$ Az általunk vizsgált kompetenciák a következők voltak: önértékelés, nyitottság, empátia, társas aktivitás, önfejlesztés, pozitív gondolkodás, egészségtudatosság, környezettudatosság, társadalmi érzé-
} 
kezők voltak. A pedagógusok a személyes és társas kompetenciák megítélésében sokkal kedvezőbben vélekednek önmagukról (ebben valószínüleg az én-erősítő mechanizmusoknak is van szerepük), mint tanítványaikról. Feltünő ugyanakkor a nagyfokú bizonytalanságuk is, ugyanis a felsorolt 15 kompetencia közül nyolc esetében a nevelök többsége nem tudta eldönteni, jellemzö-e tanítványaira vagy sem azok megléte. Különösen meglepő ez olyan kompetenciák esetében, mint az empátia, a pozitív gondolkodás, az egészség- és környezettudatosság, vagy a felelősségérzet, mivel ezek megléte vagy hiánya direkt módon megtapasztalható a nevelési folyamatban. A felsorolt kompetenciák között nem differenciáltak a pedagógusok, mindegyik közvetítését fontosnak vagy nagyon fontosnak tartják. Több esetben is tapasztalható volt, hogy az amúgy is túlzó önképükhöz képest is, még inkább hangsúlyozzák azok iskolai fejlesztésének szükségességét.

A viszonylag kevés számú empirikus kutatás nem teszi lehetővé a pedagógusok kompetenciákkal kapcsolatos véleményének átfogó elemzését, bizonyos metodikai és tartalmi következtetések azonban mégis levonhatók. A kompetenciák mérése - már a fogalom tartalmi összetettsége miatt is - komoly módszertani feladat, mely kizárólag közvetett kutatási módszerekkel aligha oldható meg (Ollé és Perjés, 2006). Az általunk bemutatott kutatások mindegyike kérdőíves kikérdezésen alapult. Metodikai szempontból úgy tünik, a kérdőíves vizsgálatok korlátozottságuk ellenére is alkalmasnak tünnek a pedagógusok szakmai nézetrendszerének, a saját szakmai tudásukkal kapcsolatos vélemények, valamint a kompetenciáról való gondolkodásuk feltárására (Nagy, 2008; Ollé és Perjés, 2006).

Rövid összegzés: A magyar pedagógusjelöltek és pedagógusok mindennapi munkájában a „hagyományos” pedagógiai funkciók ellátása kap nagyobb hangsúlyt, szemben az oktatáspolitika által kiemelt kompetenciafejlesztéssel. Szerepfelfogásuk korlátozott, főképp az osztálytermi feladatokra fókuszáló. A pedagógusok paradox módon saját kompetenciáikat jó színvonalúnak ítélik meg, mégis deficitről számolnak be felkészültségüket illetően. Saját alkalmasságukat vagy nem tudják differenciáltan értékelni, vagy az ténylegesen is differenciálatlan. Szembetűnő a nevelők bizonytalansága a tanítványaik kompetenciáinak megítélésében. A pedagógusok számára szervezett képzések, továbbképzések szemléletváltásra megfelelőek, de a kompetenciák begyakorlása hosszabb időt feltételez. A pedagógusok gyakorta fogalmaznak meg hiányérzetet a pedagógusképzéssel és a továbbképzésekkel kapcsolatban, így például a reflektív szemlélet kialakulásához, az eltérö képességü tanulók neveléséhez és oktatásához, a módszertani megújuláshoz, a kommunikációs technikák fejlesztéséhez, valamint az eltérő érdeklődésű tanulók motiválásához kérnek nagyobb segítséget.

kenység, etikai érzék, felelősségérzet, szervezőképesség, döntésképesség, esztétikai érzék, harmónia. A felhasznált kompetenciarendszer megtalálható: Veres Gábor (2004, szerk.): Mátrix. Az integrált természetismeret tantárgy kereszttantervi tartalma. Kézirat, 33-35. oldalán. 


\section{Az interperszonális kommunikáció}

A kommunikációt legegyszerübben úgy határozhatjuk meg, mint információk átvitelét egy feladótól egy címzetthez. Bármely kommunikációnak négy fontos eleme van: (a) a feladó (forrás), aki kódolja (b) az üzenetet, (c) amely egy meghatározott csatornán kerül átvitelre a (d) vevőhöz, aki dekódolja azt. További sajátossága, hogy dinamikus kölcsönös folyamat, mely a korábban szerzett ismeretekre és a partnerek közös történetére épít (Forgas, 1989).

Többféle felosztása ismert, a partnerek kapcsolata alapján megkülönböztetünk személyes és tömegkommunikációt, a szabályok kötöttsége alapján lehet intézményes és nem intézményes. Azon az alapon is csoportosíthatók, hogy milyen célból alkalmazzuk. Ha a kommunikációhoz más szándék nem kötődik, akkor cél jellegü, míg eszközjellegü, ha segítségével akarunk valamit elérni. Claude Flament az interperszonális kommunikációt reakciótípusok szerint (pozitív reakciók, válaszok, negatív reakciók) szocioemocionális zónák szerint (pozitív, semleges, negatív) és problématípus szerint (kommunikációs, értékelési, befolyásolási, feszültségi, integrációs) osztályozza (Zrinszky, 1990).

Az interperszonális kommunikáció a kommunikáció legősibb és legfontosabb formájának tekinthető az emberek információcseréjében, mind onto-, mind filogenetikailag az ember ön- és éntudata, személyisége, viszonyulása a másik emberhez, társadalomhoz, az interperszonális kommunikáción keresztül valósul meg (Fülöp, 1996). Benne a verbális és a nem verbális elemek egyidejüleg fordulnak elö, mely mindig két szinten zajlik. Az egyik szint a tudatos (direkt) kommunikáció, mely lehet verbális és nem verbális, és a másik szint az ezzel párhuzamosan futó metakommunikáció.

Az iskola különösen jelentős terepe a kommunikációnak, hisz a kommunikáció színvonala éppúgy kihat a tanulók tanulmányi teljesítményére, mint a tanárok és diákok között kialakuló interperszonális kapcsolatok minőségére. Az osztálytermi kommunikáció három szintjét szokták megkülönböztetni:

- intraperszonális (egyénen belüli) kommunikáció: bele tartozik a gondolkodás, a hangos beszéd, a jegyzetek készítése;

- interperszonális (két személy közötti) kommunikáció: mikor a tanár a diáknak, a diák a tanárnak, illetve a diák a diáknak küld üzenetet, fó jellemzője a kommunikáción belüli többszöri szerepcsere (kezdeményező-reagáló szerep);

- csoportkommunikáció: mikor a tanár a csoportnak, csoport a tanárnak, és a tanulók egymásnak küldhetnek üzenetet, ilyen típusú kommunikáció van viták, előadások, magyarázatok, illetve csoportosan végzett tevékenységek esetén (Szitó, 2007). 
A nevelési-oktatási folyamatban a kommunikáció két főszereplője mindig is a tanár és a diák volt. Mára azonban alapjaiban változott meg az iskolai kommunikáció minősége, mely leginkább a következő okokra vezethető vissza:

- Az emberi tőke és hozzá kötődően az oktatás szerepének felértékelődése az Európai Unióban: melyben kulcsszerepe van a kommunikációs kompetenciának, interperszonális készségeknek és ICT (information and communication technology) használatának. Ezek megszerzésére a formális oktatás mellett megjelennek új lehetőségként az informális tanulási módok (Imre, 2001).

- Az új elektronikus technológiák másfajta kommunikációs technikákat eredményeztek, melynek hatásai az iskolákban is erösen megfigyelhetők. Ahogy Dessewffy Tibor és Galácz Anna (é. n.) fogalmaz egy tanulmányában, a viták tárgya sok esetben még mindig az, hogy használata digitális szakadékot vagy csökkenő egyenlőtlenséget eredményez, más dimenzióból nézve az izolációhoz, vagy a bővülő társadalmi kapcsolatokhoz segítik-e felhasználóját. Tény azonban, hogy a digitális technológiák hatására egyfelöl újra és új hangsúlyt kapott az emberi kommunikáció legősibb típusa a vizuális és képi információk közlése, de szembesülnünk kell ugyanakkor az emberi kapcsolatokat beszükítő, inkább passzivitásra és befogadásra késztető, valamint a vizuális klisék uniformizáló hatásaival egyaránt.

- Megváltozott tanulói sajátosságok: Marc Prensky (2001) tanulmányában az iskolák számára teljesen új ,jelenségként" mutatja be a digitális bennszülöttek világát, akikről az oktatási rendszer egyáltalán nem vesz tudomást, holott eredményes oktatásukhoz szükség lenne - mint ahogy a szerző mondja - egy új, digitális bennszülötteknek való módszertan kitalálására. E generáció sajátja, hogy életük első percétől a digitális világ veszi őket körül, melynek eredményeként másképp gondolkodnak, másképp dolgozzák fel az információkat, így a bennszülöttek számára az iskolai kommunikáció elavultnak, érthetetlennek tünik.

- Családi szocializációs hatások: kutatások támasztják alá, hogy a gyermek kommunikatív kompetenciája - mint otthonról hozott kompetencia - nagyban hozzájárul az iskolai sikerekhez, ugyanígy a gyermek olvasási teljesítménye összefügg azzal, hogy a szülők mennyire tartották értéknek az olvasást, illetve az annak tanulását elösegítő készségeket (Szitó, 2007).

- A tradicionális és modern iskolai kommunikáció közti különbség: a hagyományos felfogás elsősorban az információk „begyüjtését” és helyes „szétosztását" hangsúlyozta, többnyire a tanártól a diákra irányuló aszimmetrikus formában, addig a modern kommunikáció sokkal befogadóbb és együttműködőbb, vagyis a kommunikáció szimmetrikus, és benne az individuális szempontok nagyobb szerepet játszanak (Szivák, 2006). 
- Az oktatási környezet: a hagyományos osztálytermi berendezés (padok szabályos sorba rendezése) és a tradicionálisnak tekinthető frontális munka, valamint a magas osztálylétszámok, és az ezzel együtt járó tantermi zsúfoltság sem kedvez az interperszonális kommunikációnak. Mára egyre látványosabb a „fellazulás” a magyar iskolákban is, gyakoribb a tanárok részéről a kooperatív, a projekt-technika, a vita, és más, személyre orientáló kommunikációs módszerek alkalmazása, vagy épp a téri és idő struktúra merevségének oldása a tantermekben (Szitó, 2007; Páskuné, 2005).

- A tanári szerep átalakulása: új elvárások fogalmazódnak meg a tanárral szemben is, a hagyományos ismeretátadás helyett tudásszervező, facilitátor szerep, melyhez módszertani megújulás is szükséges, mint a multimédia felhasználása vagy a reflexivitás. A tanári kommunikáció terén a megújulás igénye a tanulókban is megfogalmazódott, mert különösen érzékenyek a tanulók a tanár megjelenésére, az oktatási kommunikációjára (strukturált, naprakész, hatékony, humoros és ,interaktív” legyen) valamint a kapcsolati, emocionális válaszokra (barátságos, érdeklődő, lelkes, őszinte) (Szitó, 2007).

Az iskolai információcserében kiemelkedő szerepe van a tanár verbális és nem verbális kommunikációjának, hiszen jórészt ezen múlik pedagógiai szándékának megvalósulása. A verbális kommunikáció szempontjából a három leggyakoribb tanulási szituáció:

- együttmüködö tanulási szituáció: mikor a felek felismerik, hogy csak akkor érhetik el céljaikat, ha rajtuk kívül mindannyian elérik céljaikat, s ez egymás közötti pozitív interakciókat teremt;

- versengő szituáció: a felek úgy vélekednek, hogy saját céljaikat csak mások legyőzése árán tudják megvalósítani, így a kommunikáció arra szolgál, hogy kiszürje a veszteseket, vagyis a kommunikáció visszafogása a cél;

- individualisztikus szituáció: úgy vélik a felek, hogy a saját céljaik elérésének semmi köze nincs ahhoz, hogy a többiek elérik-e céljaikat vagy sem, így minimális kommunikáció folyik a felek között (Tóth, 1996).

Pedagógiai nézőpontból a cél az együttműködést igénylő osztálytermi szituációk bátorítása és a másik kettő háttérbe szorítása.

A verbális kommunikációval szemben a nem verbális kommunikáció iskolai (osztálytermi) vizsgálata alig került még a kutatások középpontjába. Holott a gesztusoknak, mimikának, testtartásnak, a tekintetnek, a személyközi távolságnak, a paralingvisztikának kitüntetett szerepe van az interperszonális kommunikációban. Míg például a „gesztus-nyelv” jól kidolgozott az iskolában, gondoljunk például a helyeslö bólintásra vagy a különböző kézmozgások (figyelmeztető, hívó mozdulatok) alkalmazására a nevelés során, addig mások, mint például a mimika, az érintés, vokális gesztusok, sokkal szegényesebbek az osztálytermekben. Ennek oka, hogy az iskolában más típusú kommunikációra kerül sor, mint a mindennapi életben, ráadásul azok is erős szabályozás alatt állnak mind a tanárok, mind a diákok részéröl. 
A nem verbális csatornák a nevelési folyamatban úgynevezett kommunikációs mintázatot alkotnak, mint:

- tanulóról alkotott benyomások: minél pozitívabb nem verbális jelzést küld a diák a tanár felé (figyel, mosolyog, bólogat), annál magasabbra értékeli a tanár a diák szociális és intellektuális képességeit;

- tanári elvárások: a pozitív tanári attitüd egy diák irányába megnyilvánul például abban, hogy többször néz rá, többet mosolyog, hosszabban beszél a diákkal;

- a tanári nem verbális kommunikatív jelzések feldolgozása: életkor függvénye a nem verbális kommunikációs jelzések felfogásának képessége, erre a fiatalabbak kevésbé képesek, nehezebben tudják dekódolni a paralingvisztikai üzeneteket éppúgy, mint a verbális és nem verbális, de egymásnak ellentmondó üzeneteket;

- a tanári nem verbális kommunikáció szerepe a tanításban, óravezetésben: ha a tanulók megbíznak a tanárban, akkor jobban figyelnek rá, barátságosabbak, melegebb hangon szólnak hozzá, melyhez a tanár mintegy öntudatlanul hozzáigazítja saját viselkedését, elégedettebb diákjaival (Tóth, 1996).

Buda Béla egy tanulmányában bemutatja az interperszonális hatásgyakorlás három legjellemzőbb iskolai mechanizmusát:

- A szituatív viselkedésbefolyásolás: ami a szociális szituációkhoz való egyszerü alkalmazkodást jelenti, mely a jutalmazás-büntetés elvén alapul. Föképp a diákok metakommunikációja lehet segítségére a tanárnak az egyénre szabott stratégia kidolgozásához. Hátránya, hogy az alkalmazkodás csupán kényszer, mely nem eredményezi a személyiség tartós változását.

- Az emberi kapcsolatokon keresztül történő viselkedésbefolyásolás: a befolyásoló és befolyásolandó közt érzelmi kapcsolat alakul ki, mely aszimmetrikus, azaz a tanár inkább irányító és szabályozó, de a kapcsolat alapja a szeretet és tisztelet. Ebben szintén a metakommunikatív eszközöknek van jelentősége, mert a szónál többet érnek a gesztusok, mint az odafordulás, a figyelem, az elfogadás.

- Azonosuláson alapuló viselkedésbefolyásolás: a személyiség (főképp a gyermek) képes arra, hogy a másik emocionális állapotába bele tudja élni magát, azaz az érzelmi beleélés feltétele az empátia. Az azonosulás során komplex viselkedési minták, motivációs rendszerek épülnek be a személyiségbe, mely hozzájárul az egyén adaptációs szintjének ugrásszerủ növekedéséhez. Ez a leghatékonyabb mechanizmus, hiszen belsővé vált viselkedésről van szó, ami lehetőséget teremt az autonóm magatartásra. 
A fenti mechanizmusok tükrében fogalmazza meg Buda Béla a pedagógusok teendöit a hatékony interperszonális kommunikáció érdekében, melyek a következők:

- a pedagógusoknak jobban oda kell figyelnie és törekednie kell a tanulók metakommunikatív megnyilvánulásainak megértésére;

- tudatosabban kell saját metakommunikációját szabályozni;

- törekednie kell a megfelelő kapcsolat kialakítására a tanulókkal, a kommunikáció segítségével;

- tudatosítania kell magában, hogy a pedagógiai szituációkban teljes személyiségével vesz részt, így gyengéi is óhatatlanul felszínre kerülnek, melyek önfejlesztéssel, önmegismeréssel alakíthatók (Budát idézi Balázs, 2000, 37-65.).

\section{A kutatás tapasztalatai}

A tanulmányban bemutatott empirikus kutatáshoz 707 Hajdú-Bihar, Jász-NagykunSzolnok, Szabolcs-Szatmár-Bereg, valamint Borsod-Abaúj-Zemplén megyei általános (alsó és felső tagozat) és középiskolai (szakiskola, szakközépiskola, gimnázium) pedagógus szolgáltatott adatot. Kérdöivünk 74 állítást tartalmazott, melyek a személyes és társas kompetenciák alábbi területeit tárták fel: én-hatékonyság, a konfliktuskezelés, az empátiás képesség, az interperszonális kommunikáció, a motiváció, az asszertivitás, az érzelmi intelligencia, a szociális problémamegoldás és az önpercepció. Az állításokkal való egyetértés mértékét ötfokú Likert-típusú skálán kellett a pedagógusoknak jelölniük, az egyáltalán nem jellemző és teljesen jellemző dimenzióban.

Vizsgálatunkban a tanárok interperszonális kommunikációjukról való vélekedését hét item segítségével vizsgáltuk. Az állítások összeválogatásánál felhasználtuk Balázs Sándor (2000) könyvének feladat és gyakorlat gyüjteményét. A kérdések közt a verbális kommunikációra, az empátiára, a viselkedés korrekciójának képességére, a nyitott kommunikációra, a másikra való odafigyelésre, illetve annak hiányára, az emocionalitásra vonatkozó állítások szerepeltek (1. ábra).

A pedagógusok interperszonális kommunikációját vizsgáló itemek átlagpontszámai 3,25 és 4,29 közöttiek. Nagy szórás mellett $(1,161)$ a tanárok felének nincsenek kommunikációs nehézségei, 45 százalékukra ez soha vagy csak ritkán jellemző, míg minden negyedik tanár $(24,4 \%)$ alkalmanként nem tudja úgy kifejezni magát, ahogy szeretné. Meglepő viszont, hogy negyedüknél (24,9\%) gyakori, míg 5,7 százaléknál állandósult problémáról van szó (Sokszor nem tudom úgy kifejezni magam, ahogy szeretném). 


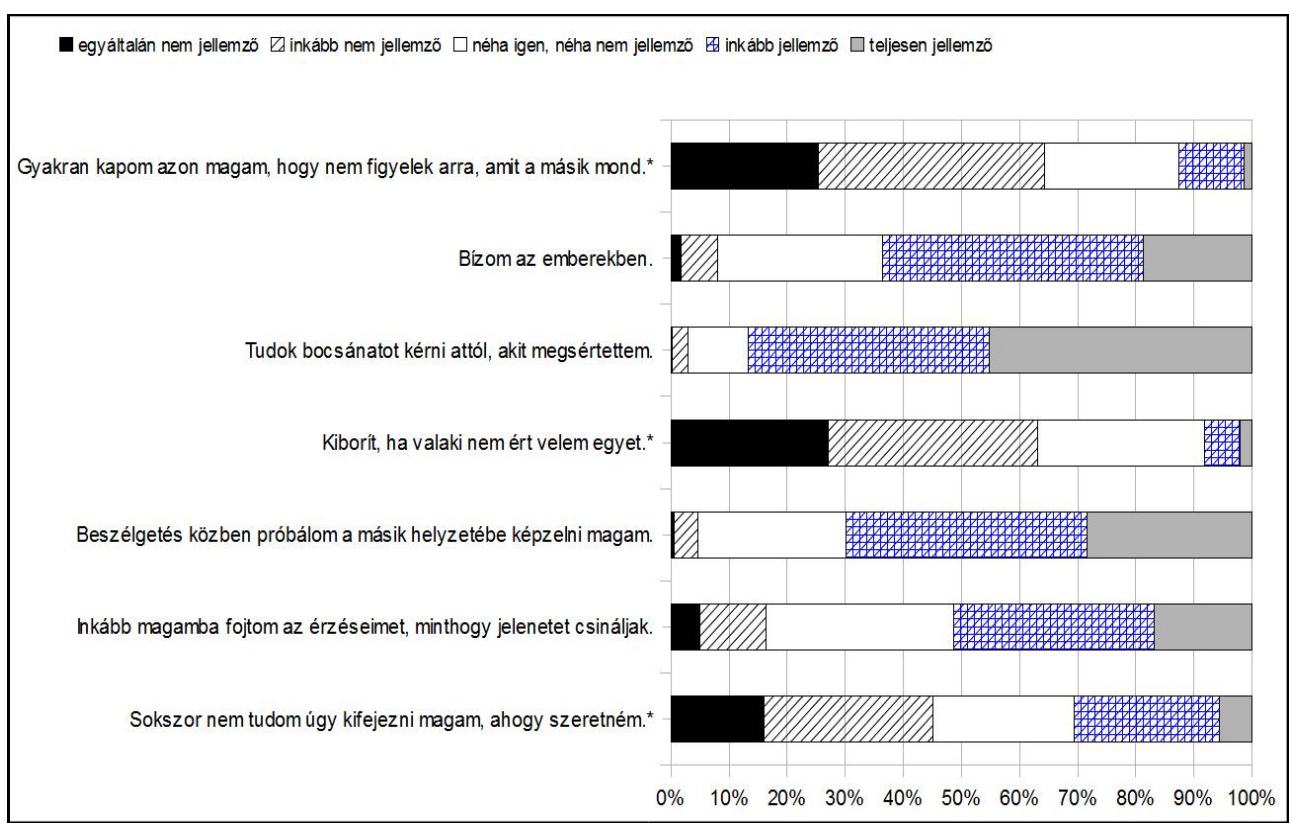

1. ábra: Az interperszonális kommunikációs képesség százalékos megoszlása az egyes itemekre lebontva $(n=704)(a *$-gal jelölt item fordított $)$

Hazai kutatások arról győznek meg bennünket, hogy az oktatási folyamatban még többségében a frontális munkaformát és az úgynevezett hagyományos módszereket (magyarázat, megbeszélés, előadás) alkalmazzák a tanárok, és azzal is tisztában vannak, mire kell ügyelniük a használatuk során (érthetö, világos, logikus felépítésü, gyerekek szintjéhez igazodó legyen) (Falus, 2001). Úgy tünik, a vizsgált tanárok közel harmadánál kommunikációs nehézségek akadályozzák a hatékony tanítást, mindez történik annak ellenére, hogy saját „korlátaikkal” elviekben tisztában vannak. Tágabb, nevelési értelemben még inkább fajsúlyos problémával állunk szemben, ugyanis ma már egyértelmű az alkalmazott nyelvi kód és az iskolai sikeresség és eredményesség közi összefüggés. ${ }^{4}$ A tanulóknak - főleg azon rétegnek, akik szociokulturális hátrányokkal küzdenek - a tananyag megértésén túl a tanár egyszerü (legalábbis annak szánt) közléseinek feldolgozása is gondot okozhat, mivel a tanárok közel harmada nem képes a kongruens kommunikációra. Tudományos vizsgálatok szerint a jelzések különböző értelmezéséből számos nevelési hiba és nevelési ártalom is keletkezhet, sőt a felnőtt szándékától épp ellenkező hatás is kiváltódhat (Buda, 1993).

\footnotetext{
${ }^{4}$ Lásd erről B. Bernstein: Class, Codes and Control (1971) című művét, vagy Bourdieu kulturális tőke elméletét.
} 
Az „Inkább magamba fojtom az éréseimet, mint hogy jelenetet csináljak” állítás magas szórása $(1,056)$ alapján a pedagógusok viselkedése meglehetősen széles skálán ingadozik. Közel hasonló arányban vannak azok, akikre inkább jellemző $(34,4 \%)$ az érzelmi visszafogottság, és azok, akik erre néha-néha képesek $(32,4 \%)$, míg 16,3 százalékra egyáltalán vagy inkább nem jellemző ez. Összességében a tanárok 51,3 százaléka erösen kontrollálja érzelmeit. Pedagógiai szempontból figyelemre méltó Gordon és Johnson irracionális hiedelmekkel kapcsolatos nézőpontja, melyről úgy vélik, hogy célja a ,jó tanár” mítoszának fenntartása. Mítosz, miszerint „a jó tanár mindig nyugodt, nem lehet kihozni a sodrából, sosem veszíti el a fejét, és sosem mutatja ki intenzív érzelmeit." Véleményük szerint a tanár is érző lény, akinek arra kell vigyáznia, hogy ne éljen vissza hatalmával, de a gyermekek csak akkor szerethetik emberi lényként tanáraikat, ha ismerik intenzív érzelmeit is (Szitó, 2007). Egyetértve a kutatók megállapításával, mindenképp hangsúlyoznunk kell ugyanakkor, hogy az érzelmek kifejezésének, szabályozásának, az érzelmekkel való megküzdésnek a megtanulása fontos része a gyermekek szocializációjának, melyben ily módon a pedagógusoknak is nagyobb szerepet kell vállalniuk annak ellenére, hogy az erős érzelmi kontroll hátterében bizonyára meghúzódik a mai magyar társadalom (médiumok) által gerjesztett vélt vagy valós odafigyelés az iskolai mindennapokra, főleg a „negatív szenzációkra”. Természetesen ez az odafigyelés mindenképp jogos, ha a tanárok szélsőséges érzelmi reakcióinak elszenvedőivé válnak a tanulók.

Mivel az interperszonális kommunikáció során a direkt és az indirekt közlések együttesen fordulnak elő, így azok mindig befolyásolják a közlő és a másik fél közötti viszonyt. Különösen igaz ez az indirekt jelzésekre, melyből meg lehet állapítani a felek érzelmi alapállását, vagy azt, hogy a személy hogyan érzi magát egyegy szituációban. Ezeknek a jelzéseknek a felfogásában, illetve a feldolgozásában van jelentősége az empátiának. Ezért tartottuk szükségesnek annak megismerését, hogy interperszonális szituációban mennyire jellemző a pedagógusokra a mások helyzetébe való beleélés (Beszélgetés közben próbálom a másik helyzetébe képzelni magam). A 3,93 átlagpont alapján azt mondhatjuk, a megkérdezett tanároknak jó az empátiás rezonancia szintje. A tanárok több mint kétharmada $(69,9 \%)$ szerint ez a képesség teljes mértékben, vagy inkább jellemző rájuk, negyedrészüknél $(25,5 \%)$ ez alkalomszerüen nyilvánul meg, mindössze 5 százalék véli úgy, hogy nem képes mások helyzetébe beleélnie magát. A kutatás empátiás hajlamot vizsgáló kérdéseihez képest ez esetben magasabb értékkel találkozunk, vagyis a tanárok valóban képesek arra, hogy beszélgetés közben ráhangolódjanak a másik mondanivalójára, ezt nevezte el Cooper (2004) alapempátiának, viszont a mélyebb empátiás képességek tekintetében már jobban megoszlik a vizsgált minta, és kevesebben is rendelkeznek ilyen képességekkel.

Az interperszonális kommunikációt egy másik aspektusból is vizsgáltuk, mégpedig, hogy mennyire jellemző a nem odafigyelés a másik mondandójára (Gyakran 
kapom azon magam, hogy nem figyelek arra, amit a másik mond). Tendenciájában a két kérdésre adott válaszok megoszlása hasonló, $\mathrm{p}<0,009$ szinten szignifikáns kapcsolatot találtunk az empátiás képesség és a másokra való odafigyelés között, tehát minél empatikusabb egy tanár, annál kevésbé fordul elő a gyenge meghallgatási képesség. Ennek ellenére elgondolkodtató, hogy a tanárok közül minden tizedik $(12,6 \%)$ nem képes odafigyelni a másikra.

Az interperszonális kapcsolatok egyik lényegi eleme a másik elfogadása, egyéniségének tiszteletben tartása, mely nem képzelhető el bizalom nélkül. Pszichológiai értelemben a bizalom a másik félre vonatkozó pozitív elvárásokat és a kockázatvállalás szándékát magában foglaló pszichológiai állapot. Egy hazai kutatási beszámoló tanulságai közt szerepel, hogy a magyar tanárok kiemelt feladatuknak tartják megteremteni az együttmüködés és a bizalom légkörét az iskolákban (Nagy, 2008). Kérdéseink közt ezért szerepeltettünk egy olyan állítást, mely az erről való vélekedésüket vizsgálja (Bízom az emberekben). A 4-es módusz szerint a legtöbbjük inkább bízik az emberekben, viszont a tanárok 8 százalékra ez egyáltalán nem jellemző. Majdnem több mint negyede a tanároknak $(28,4 \%)$ néha bízik az emberekben, máskor pedig nem, és kétharmadnyian $(63,6 \%)$ vannak azok, akik képesek a másik feltétel nélküli elfogadására. A kutatásunk nem vizsgálta, mi áll a tanárok bizalmának hátterében, de a túl erôs bizalom kihasználhatósághoz, az együttmüködésre hatva homogenitáshoz, illetve szociális és kognitív kategorizációs torzításokhoz vezethet, míg a túl alacsony bizalmi szint is akadályává válhat a másikkal való hatékony együttmüködésnek, melyre mindenképp oda kell figyelni az iskolai interperszonális kommunikációban (Sass, 2003).

A személyek közötti kapcsolatok velejárója, hogy konfliktusok alakulnak ki a felek között, melyek megoldásmódja éppúgy lehet romboló hatással a kapcsolatokra, mint kezdete a stabilizálódásának. Ebben játszik szerepet, hogy képesek vagyunk-e bocsánatkérésre, mellyel helyreállítható az a bizalom, ami a további együttmüködést szolgálja (Tudok bocsánatot kérni attól, akit megsértettem). A kutatásban résztvevő pedagógusok jelentős többsége (módusz: 5, szórás 0,776 ) azt állítja, tud bocsánatot kérni attól, akit megsértett. 3 százalék körüli mindössze azok aránya, akik soha vagy csak ritkán kérnek bocsánatot a másiktól, és minden tizedik $(10,4 \%)$ tanárnál ez a szituációtól függ. Nagytöbbségük $(86,7 \%)$ ugyanakkor gyakran vagy mindig törekszik a bizalom helyreállítására a másik féllel. A bizalom és a megbocsátás képessége összefügg $(\mathrm{p}<0,0001)$, azok a tanárok képesek leginkább bocsánatot kérni a másiktól, akik bíznak is az emberekben. Azoknál a pedagógusoknál pedig akik személytől, szituációtól teszik függővé a bizalmukat, szintén személytől, szituációtól fog függeni a szándékuk a kapcsolatok helyreállítására. Pedagógiai szempontból ez az utóbbi beállítódás a tanárok részéről hozzájárulhat ahhoz, hogy lesznek olyan tanulói körök, akik számára nem adatik meg, illetve esetlegessé válhat a bizalmon alapuló interperszonális kapcsolat az iskolában. 
Fontos mutatója a tanár-diák kapcsolatnak a pozitív színezetủ interperszonális viszony is, melynek alapvetö tartalmi eleme az érzelmi stabilitás. Kutatásunkban a tanárok közel kétharmada (63,1\%) azt állítja magáról, képes indulatait kontroll alatt tartani akkor is, ha nem ért vele egyet valaki (Kiborit, ha valaki nem ért velem egyet). Azonban 8 százaléka a tanároknak nem tekinthető érzelmileg stabilnak, mivel ök sokszor vagy mindig impulzívak, míg a tanárok közel harmadának $(28,7 \%)$ szituációfüggő a reakciója. Érdekes adalékul szolgálhat egy 2002-2005 között folyó OTKA kutatás eredménye ${ }^{5}$, melyben fontosnak tartanák a pedagógusok kontrollfunkcióinak fejlesztését azért, hogy megtanulják a feszült helyzetekben az indulati életük uralását, így csökkenteni lehetne az érzelemközpontú megküzdések dominanciáját, mely hozzásegítené a tanárokat a helyzet uralásához.

A pedagógusok személyes és társas kompetenciáinak sajátosságait különböző háttérváltozók alapján is vizsgáltunk. Minden háttérváltozó esetében találtunk szignifikáns összefüggést valamely állítással kapcsolatban, de leginkább a nemi hovatartozás, a tanítási idő és a pályával való elégedettség gyakorol hatást az interperszonális kommunikációra. (Lásd 1. táblázat)

A nemek eltérő kommunikációja számos kutatás tárgyát képezi. A nemek közti kommunikációs különbséget a szakirodalmak gender-különbségnek tekintik, melyek a szocializációs és kulturális eltéréseken alapulnak (Tannen, 2001). Ezek a sajátosságok akár a mindennapi társalgásban is megmutatkoznak, mert míg a nők az egyetértésre, a kapcsolat folytonosságára törekszenek, addig a férfiak a szerep és a státusz fenntartására, az előbbi intuitív és emotív, az utóbbi érvelő és dialektikus (Aczél, 2007). Ezek után talán nem meglepö, hogy a nőkre inkább jellemző a performatív kompetencia. Vizsgálatunkban is közülük vannak többségben $(56,1 \%)$, akik számára nem okoz gondot úgy kifejezniük magukat, ahogy szeretnék, míg férfiak közt az arány 41,6 százalék. A férfiak majd harmadának $(31,1 \%)$ viszont ez csak néha vagy egyáltalán nem sikerül, de a nőknél sem alacsony az arány, mert 23,5 százalékuk küzd hasonló gondokkal. Mindezek tükrében célszerü számolnunk a férfiak és nők - akik egyben tanárok is - közti kommunikációs különbségekkel a tanár-diák közti személyes kapcsolatok alakulásakor, mivel az eltérő kommunikáció akár kommunikációs félreértéseket is eredményezhet.

\footnotetext{
${ }^{5}$ A kutatás zárójelentése, melyet Gáspár Mihály vezetett megtalálható „A személyiség belső feltételeinek és stabilitásának alakulása a pályaszocializáció függvényében" címmel a http://real.mtak.hu/ 237/1/37514_ZJ1.pdf oldalon.
} 


\begin{tabular}{|c|c|c|c|c|c|c|c|c|}
\hline \multirow{10}{*}{ 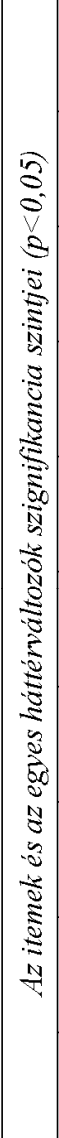 } & marad-e & & & & & & $\overline{8}$ & $\overline{8}$ \\
\hline & $\begin{array}{l}\text { pályúval való } \\
\text { eléggdettség }\end{array}$ & $\tilde{\delta}_{0}$ & & & & ळे & $\overline{8}$ & $\bar{\delta}$ \\
\hline & $\begin{array}{c}\text { átlagos } \\
\text { osztálylétszám }\end{array}$ & & & $\stackrel{\infty}{\circ}$ & & & & \\
\hline & $\begin{array}{c}\text { iskola } \\
\text { nagysága }\end{array}$ & & & & & & & \\
\hline & település & & & $\stackrel{0}{\circ}$ & & & & \\
\hline & megye & & & & & & & \\
\hline & intézménytipus & & & 吕 & & & $\bar{\Xi}$ & \\
\hline & $s z a k$ & & & $\stackrel{n}{0}$ & & 8. & & \\
\hline & tanitási idö & & $\stackrel{J}{\mathscr{C}}$ & ठิ & $\stackrel{\infty}{0}$ & & $\overrightarrow{8}$ & \\
\hline & nem & $\stackrel{\infty}{\circ}$ & $\bar{\Xi}$ & $\overrightarrow{8}$ & & 㢳 & & \\
\hline 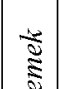 & szórása & $\stackrel{5}{=}$ & $\stackrel{8}{8}$ & $\begin{array}{l}\mathbb{D} \\
\infty \\
0\end{array}$ & $\begin{array}{l}\frac{1}{2} \\
2 \\
0\end{array}$ & $\stackrel{\circ}{\stackrel{2}{0}}$ & $\begin{array}{l}1 \\
0 \\
0 \\
0\end{array}$ & $\underset{8}{\bar{s}}$ \\
\hline พั้ & átlaga & $\hat{m}$ & $\underset{m}{5}$ & $\stackrel{2}{2}$ & $\begin{array}{l}\infty \\
\infty \\
\infty\end{array}$ & $\ddot{\vartheta}$ & $\stackrel{m}{m}$ & $\stackrel{0}{i}$ \\
\hline & 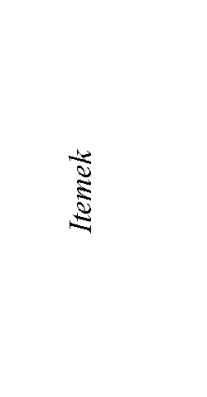 & 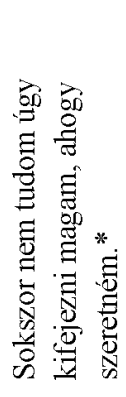 & 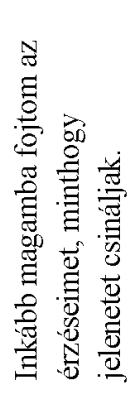 & 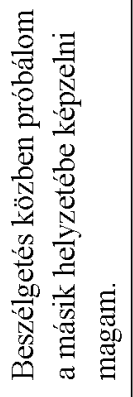 & 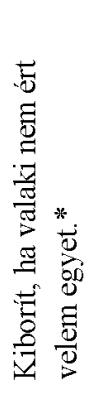 & 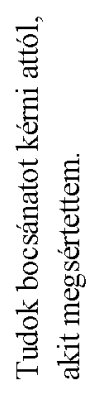 & 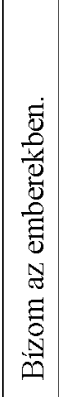 & 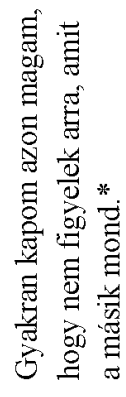 \\
\hline
\end{tabular}


A fenti okok szerepet játszhatnak abban is, hogy inkább a nők képesek az érzelmeik visszafogására 52,2 százalékuk erre mindig vagy legtöbbször képes, a férfiaknál 45 százalék ez az arány. A férfi tanárok közel negyede $(23,4 \%)$ nem igazán fogja vissza érzelmeit, és a nők 14,8 százalék a is hajlamos arra, hogy jelenetet csináljon egy-egy szituációban. Hasonlóképp az eddigiekhez a nők előnyben vannak férfi kollégáikkal szemben az empátiás képességük tekintetében is, ez esetben is a tanárnők háromnegyede $(74,4 \%)$ véli úgy, hogy magas szinten képes a másik helyzetébe való beleélésre, míg a férfiaknál ez az arány 50 százalék körüli. A tudok bocsánatot kérni állításnál mindkét nem magasra értékeli ilyen irányú képességeit $(4,16$ és 4,32 átlagpont), bár gyenge összefüggés $(p<0,045)$ mégis tapasztalható a nők javára, ők megbocsájtóbbak férfi társaiknál.

A tanitásban eltöltött időt alapul véve az érzelmek elfojtásának képessége leginkább a legrégebben pályán lévőkre jellemző, ennek a korosztálynak 60 százaléka teljes mértékben tudja kontrollálni érzelmeit, és náluk a legalacsonyabb azok aránya $(12,6 \%)$, akik nem képesek erre. Mindez összefüggés behozható az idősebb korosztály azon sajátosságával, hogy lényegesen „kimunkáltabbak” már karakterjellemzőik, magasabb konfliktustüréssel, nagyobb toleranciával rendelkeznek (Gáspár M., é. n.).

A legfiatalabb korosztály fele $(51,2 \%)$ szintén inkább elfojtja érzelmeit, míg a 12-23 éve tanító középgenerációnál ez az arány 44,2 százalék, és közülük majd minden ötödik tanár (18,8\%) egyáltalán nem képes az emocionális visszafogottságra. A korábban már hivatkozott OTKA kutatásban is megállapításra került, hogy a 24-40 év körüli pedagógusgeneráció sérülékenyebb a munkahelyi stressz-faktorok által, több a „burn out” szindrómával küzdők száma is, melyet egyfelöl arra vezetnek vissza, hogy az idősebb generáció kiégés szempontjából már szelektálódott, és jobban kimunkáltak az önirányultság karakterjellemzői is náluk, másfelöl, hogy hiányoznak az ezt csökkentő olyan szervezeti feltételek az iskolákból, mint például szervezeten belüli tréningek, vagy az önsegítő csoportok. Ezek után talán nem meglepő, hogy szintén a középgeneráció tagjai közt vannak a legtöbben azok $(40,9 \%)$, akik alkalomfüggően vagy rendszeresen elveszítik érzelmi kontrolljukat, ha nem értenek velük egyet. Közel ugyanilyen arányban $(39,1 \%)$ reagálnak így a pályakezdők is hasonló szituációban, és legkevésbé - bár még mindig magas arányban - a 23 évnél régebben tanítóknál $(33,7 \%)$ tapasztaltuk az önszabályozás hiányát. Az emberekben való bizalom és a másik helyzetébe való beleélés képessége az életkor elörehaladtával nő kutatásunk tapasztalatai szerint. Legnagyobb különbséget a bizalom megítélésében találunk a három korcsoport közt. A legidősebbek sokkal inkább bíznak társaikban (átlagpont 3,91), mint a legfiatalabbak (átlagpont $3,56)$. A legidősebb generáció háromnegyede $(73,3 \%)$ jellemzőnek tartja magára, hogy tud másokban bízni, míg a 1-11 éve pályán lévők alig több mint fele $(52,9 \%)$, és minden tizedik pályájának elején lévő tanár teljes mértékben bizalmatlan a másik irányában. Az empátiás képességben ekkora eltérést nem tapasztaltunk, a három 
korosztály átlagpontjai 4,04 és 3,82 közöttiek. A pályakezdők esetében valószínüsíthető, hogy a bizalom hiánya összefüggésbe hozható a kezdés kritikus, problémákkal terhelt időszakával (Szivák, 1999).

A pályával való elégedettség és a kommunikációs nehézségek közti összefüggés erős szignifikancia szint mellett $(\mathrm{p}<0,002)$ azt jelzi, hogy a pályájukkal egyáltalán nem elégedetteknek komoly kommunikációs problémáik vannak, mivel közel felüknek $(46,8 \%)$ szinte mindig gondot jelent pontosan megfogalmazni gondolataikat, és csak negyedüknek $(25,6 \%)$ nincsenek kifejezési gondjai. Ugyanakkor a probléma megfordítása is igaz lehet, a közlésképtelenség, a kommunikációs félreértés hozzájárulhat a pályával való elégedetlenségükhöz. Különösen figyelemre méltó ez akkor, mikor a pályaválasztásukkal nagyon elégedettek 70 százaléka és az elégedettek 48,6 százaléka számára nem jelent nehézséget gondolataik megfogalmazása. A bocsánatkérés gyakorisága ugyancsak a pályával való elégedettséggel egyenes arányban növekszik, az átlagpontok 3,89 és 4,65 közöttiek. Az egyáltalán nem elégedettek között vannak legtöbben (27,7\%), akik alkalomtól, személytől teszik függővé, hogy hajlandók-e a kapcsolatok normalizálására. Valószínüleg azokkal tudják a pályájukkal elégedetlen tanárok kapcsolataikat normalizálni, akik elfogadják, támogatják őket „áldozati” szerepük gyakorlásában. A többieknél, így például a tanársággal elégedetteknél sőt még az inkább elégedteleneknél is 85 százalék fölötti a másiknak való megbocsájtás hajlandósága. Még jelentősebb eltéréseket találunk a bizalmat illetőleg, sokkal inkább bíznak az emberekben a pályájukkal elégedettek (átlagpont 4,13), mint akik nem találták meg számításukat a pályán (átlagpont 3,54). Ez utóbbi csoport 52,1 százalékára inkább jellemző a bizalom, de megint közülük kerülnek ki legmagasabb arányban $(39,1 \%)$ azok, akik csak néha-néha tudnak bizalommal tekinteni a másikra. Azoknál, akik jól érzik magukat a pályán a másik elfogadásának mértéke 80 százalékos. Hasonlóképp a másikra való odafigyelésben is sokkal hatékonyabbak azok, akik jól érzik magukat a pályájukon, mint akik nem. A pályájukkal elégedetlenek 21,3 százaléknál igen gyakori, hogy nem mutatnak érdeklődést a másik mondanivalója iránt, míg az elégedettek esetében ez csak 6,5 százalékukra jellemző.

A pályán maradás szándékára $(\mathrm{p}<0,0001)$ erősen kihat, hogy mennyire képes a tanár a másikra figyelni, azok közt a legalacsonyabb az erre való képesség, akik a pályamódosítást fontolgatják. Közülük 17,8 százaléknál ez állandó problémát jelent, de minden negyedik tanárnál is csak eseti az odafigyelés. A másikban való megbízás képességénél ismét megállapítható, hogy azok bíznak legkevésbé $(15,8 \%)$ a másikban, akik el akarják hagyni a pályát, míg akik azzal elégedettek ez az arány csak 3,8 százalék. Kutatásunk tapasztalata szerint a másikra való nem figyelés illetve a másik elfogadásának, az együttmúködésnek a hiánya hozzájárul a pályaelhagyási szándék megfogalmazódásához.

Az interperszonális kommunikáció során a mások helyzetébe való beleélés képessége összefügg $(\mathrm{p}<0,015)$ a tanárok választott szaktárgyával is. Leginkább a ta- 
nítók (4,06 átlagpont), a humán tárgyakat oktatók (4,05 átlagpont), a napközi otthoni és a kollégiumi nevelők $(4,00)$ empatikusak, míg a reál és a szakmai tárgyakat tanítók $(3,79$ és 3,66) alacsonyabbra értékelik ilyen jellegü képességeiket. Mindebböl az is következik, hogy intézménytípus tekintetében leginkább az általános iskolák alsó tagozatán tanítók (4,05 átlagpont) törekszenek jobban az azonosuláson alapuló kommunikációra, majd a szakközépiskolai és felsős nevelők (3,97 és 3,94 átlagpont), és meglepő módon a gimnáziumi tanárok zárják a sort (3,6 átlagpont). A gimnáziumban tanítóknál kiemelkedően magas azoknak az aránya (13,9\%), akik nem is tesznek kísérletet erre, holott minden más intézménytípusban 5 százalék alatt vannak az egyáltalán nem empatikus tanár személyiségek. A szándék a megbocsátásra ugyancsak a napközi otthoni és kollégiumi nevelöknél a legjellemzőbb $(4,55$ átlagpont), de a többi szak esetében is magas 4,31-4,36 közötti átlagpontokkal találkozhatunk, melytől kissé elmaradnak most is a reáltárgyak oktatói (4,13 átlagpont). A másik emberrel szembeni bizalmatlanságnak is vannak intézményi vonatkozásai $(\mathrm{p}<0,011)$. Ez esetben is az alsó tagozaton tanítók képesek leginkább megbízni a másikban (3,84 átlagpont), őket a szakközépiskolai és felső tagozatos tanárok követik (3,77 és 3,74 átlagpont), míg a sort a szakiskolai (3,47 átlagpont) és gimnáziumi nevelők (3,45 átlagpont) zárják. Ez utóbbi intézményekben 15 százalék alatti a másikat feltétel nélkül elfogadók aránya, míg a többi intézményben 17-23\% közti az arány, viszont 31-38 százalék közt vannak azok, akiknél ez kontextusfüggő. A tanár-diák kapcsolatban kiemelkedő szerepe van a bizalom fenntartásának, hisz hozzájárul a kollektív ,jó közérzet" kialakulásához. Kutatásunk azt mutatja, hogy főképp a középiskolákban vannak e téren gondok. A bizalmatlanság hátterében ugyanúgy meghúzódhat a pedagógusok kapcsolati bizonytalansága mint a kedvezőtlen tapasztalatok, aminek eldöntésére kutatásunk nem vállalkozott. Ugyanakkor megjegyzendő, aki bizalmatlanságot kommunikál, az bizalmatlanságot vált ki.

Összegzésként megállapítható, a tanárok közel harmadának gyakran vagy állandóan kommunikációs gondjai vannak, mely megnehezíti egyes tanulói csoportok számára a kommunikációs jelzések dekódolását, amely tanulmányi és nevelési problémákhoz egyaránt vezethet. A tanárok fele erősen kontrollálja érzelmeit, ami hozzásegíti öket a ,jó tanár" mítosz fenntartásához, viszont nem segíti a tanulókat az érzelmek kifejezésének, szabályozásának és az érzelmekkel való megküzdés megtanulásában. Az erős érzelmi visszafogottság ráadásul számos kommunikációs félreértés forrása lehet. Empátiás képességüket magasra értékelik, de minden tízedik pedagógus elismeri, nem képes odafigyelni a másikra. A másik iránti bizalom és a bizalom helyreállításának képessége (megbocsátás) nagytöbbségüket jellemzi, de 13 százalékuknál a bizalom és a megbocsátás is személyfüggő, ami azt eredményezheti, hogy vannak olyan tanulói csoportok, akiknek nincs is esélye a tanár-diák kölcsönös bizalmán alapuló kapcsolatra az iskolában. A performatív kommunikációban, az empátiában és az érzelmek kontrollálásában eredményesebbek a nők. Az érzelmek elfojtása és a nem megfelelő kontroll miatt legsérülékenyebb a közép- 
generáció, míg a másik iránti bizalom főképp a legrégebben pályán lévőkre jellemző. A pályájukkal elégedettek hatékonyabbnak érzik magukat a verbális kommunikációban, nyitottabbak, empatikusabbak is, mint az elégedetlenek.

\section{Irodalom}

Aczél Petra (2007): A nem. Igen vagy nem? Gender-különbségek retorikai és szociálpszichológiai megközelítésben. In: A. Jászó Anna - Aczél Petra (szerk.): A memória és a szónoki beszéd. Trezor Kiadó, Budapest, 59-73.

Balázs Sándor (2000): A pedagógiai kommunikációs képességek fejlesztésének elméleti és gyakorlati problémái. OKKER Kiadó, Budapest.

Baracsi Ágnes (2009): Személyes és társas kompetenciák a pedagógusok szemszögéből. In: Tudományos körkép 2007-2008. Élmény '94 Bt., Nyíregyháza, 163-179.

Buda Béla (1993): Az empátia... a beleélés lélektana. EGO SCHOOL. BT., Budapest.

Cooper, B. (2004): Empathy, Interaction and Caring: Teachers' Roles in a Constrained Environment, Pastoral Care, 12-21.

http://aokk.jamk.fi/learning/educso/tekstit/EmpathyInteractionandCaringartikkeli.pdf

Dessewffy Tibor, Galácz Anna (é. n.): „A dolgok új rendje” Technológiai diffúzió és társadalmi változás. http://www.nhit.hu/data/53241/DessewffyGalaczDiffuzio.pdf

Falus Iván (2001): Az oktatási módszerek kiválasztására és alkalmazására vonatkozó nézetek. In: Golnhofer Erzsébet - Nahalka István (szerk.): A pedagógusok pedagógiája. Nemzeti Tankönyvkiadó Rt., Budapest, 232-260.

Forgas, J. P: (1989): A társas érintkezés pszichológiája. Gondolat, Budapest.

Fülöp Géza (1996): Az információ. ELTE Könyvtártudományi Informatikai Tanszék, Budapest. www.mek.iif.hu/porta/szint/.../informat/azinform/html/tartalom.html

Gáspár Mihály (é. n.): A személyiség belsö feltételeinek és stabilitásának alakulása a pályaszocializáció függvényében. OTKA pályázat zárójelentése.

http://real.mtak.hu/237/1/37514_ZJ1.pdf

Imre Anna (2001): Emberi és/vagy társadalmi tőke. Educatio, 3. 601-605.

Nagy Mária (2008): Tanári kompetenciák - nemzetközi összehasonlítás. Pedagógusképzés, 3. $21-41$.

Ollé János, Perjés István (2006, szerk.): A katedra árnyékában. Aula Kiadó Kft., Budapest.

Páskuné Kiss Judit (2005): A tantermi kommunikáció értelmezésének elméleti alapjai. In: Sarokpontok. Szolnoki Főiskola, Szolnok, 21-31.

Prensky, M. (2001): Digitális bennszülöttek, digitális bevándorlók. In: On the Horizon. NCB University Press, No. 5.

http://goliat.eik.bme.hu/ emese/gtk-mo/didaktika/digital_kids.pdf

Sági Matild (2006): A tanári munka értékelése és az iskolai eredményesség. In: Lannert Judit Nagy Mária (szerk.): Az eredményes iskola. Adatok és esetek. Országos Közoktatási Intézet, Budapest.http://www.oki.hu/cikk.php?kod=EredmenyesIskola-07_sagi_tanarimunka.html

Sass Judit (2003): Szervezeti bizalomminták az iskolában - A tanárok bizalom-forrásai. In: III. Országos Neveléstudományi Konferencia 2003, MTA PB, Budapest, 326. 
Szekszárdi Júlia (2006): Az iskolák belső világa. In: Halász Gábor és Lannert Judit (szerk.): Jelentés a magyar közoktatásról. Országos Közoktatási Intézet, Budapest, 279-311.

Szitó Imre (2007): Kommunikáció az iskolában. Argumentum Kiadó, Budapest.

Szivák Judit (1999): A kezdő pedagógus. Iskolakultúra, 4. 3-13.

Szivák Judit (2006): Kommunikáció az iskolában. In: Golnhofer Erzsébet (szerk.): A gyakorlati pedagógia néhány kérdése. Az iskolák belső világa. Bölcsész Konzorcium, Budapest, 29-39.

Tannen, D. (2001): Miért értjük félre egymást? Tinta Könyvkiadó, Budapest.

Tóth László (1996): Csoportfolyamatok az osztályban. In: Balogh László (szerk.): Fejezetek az alkalmazott lélektan köréből. KLTE Pszichológiai Intézet, Debrecen. 149-160.

Veres Gábor (2004) szerk.: Mátrix. Az integrált természetismeret tantárgy kereszttantervi tartalma. Kézirat. Készült a Közgazdasági Politechnikum, az Országos Közoktatási Intézet együttműködésével, és az Oktatási Minisztérium támogatásával.

Zrinszky László (1990): A kommunikáció. I. kötet. Pécs, 17-31. 